\title{
Ocorrência de Trypanosoma vivax em bovinos leiteiros no estado de São Paulo
}

Karoline Koether, Ana Luísa Albuquerque, Luiza Stachewski Zakia, Fernanda Panseri Rodrigues, Regina Kiomi Takahira, Anderson Kloster Munhoz, José Paes de Oliveira-Filho, Alexandre Secorun Borges'

Faculdade de Medicina Veterinária e Zootecnia, Universidade Estadual Paulista (UNESP), Botucatu, SP, Brasil

*Autor correspondente

e-mail: asborges@fmvz.unesp.br

\section{Resumo}

O Trypanosoma vivax é um protozoário que acomete herbívoros domésticos. $\mathrm{O}$ aumento da ocorrência do T. vivax em rebanhos bovinos esta relacionado à facilidade de transmissão por moscas hematófagas. No Brasil, a maior prevalência é observada na região Norte do país e no Pantanal, sendo relatado em 2011 o primeiro surto no estado de São Paulo. O objetivo deste trabalho é descrever um surto de T. vivax em bovinos em uma propriedade leiteira em São Paulo. A propriedade possuía um total de 200 bovinos leiteiros. Foram realizadas visitas à propriedade devido à queixa de emagrecimento progressivo, apatia, hiporexia e queda de produção de 37 vacas, além de histórico de aborto de duas vacas e mortalidade de 15 vacas nos últimos 15 dias. Durante a visita, observou-se a presença de grande quantidade de moscas e uso de agulha compartilhada para aplicação de ocitocina nas vacas em lactação. Além disso, alguns bovinos adultos foram adquiridos de diversas regiões do país, não sendo realizada quarentena. Amostras sanguíneas com anticoagulante de 70 vacas adultas foram colhidas para realizar diagnóstico diferencial de anaplasmose, babesiose e tripanossomíase. 0 diagnóstico de tripanossomíase foi confirmado no esfregaço de capa leucocitária de 38,6\% (27/70) dos animais, sendo o T. vivax identificado nestas amostras por biometria. Com o objetivo de aumentar a sensibilidade diagnóstica, optou-se em realizar a PCR utilizando primers específicos para o T. vivax (TviCatL1 e DT0155), descritos na literatura, em 30 amostras negativas no esfregaço da capa leucocitária. Cerca de 66,6\% (20/30) das amostras consideradas negativas no esfregaço tornaram-se positivas na PCR. Em virtude do diagnóstico de tripanossomíase, foi instituído o tratamento com aceturato de diminazene $(3,5 \mathrm{mg} / \mathrm{kg})$ e cloreto de isometamidium $(0,5 \mathrm{mg} / \mathrm{kg})$ via intramuscular, não somente nos animais acometidos mas em todos os bovinos da propriedade, além da indicação de alteração no manejo da propriedade como manutenção do ambientes limpos, controle de moscas, quarentena dos animais introduzidos nas propriedades e a utilização de agulha descartável para administração de medicamentos. 
Deve-se considerar o T. vivax como diagnóstico diferencial de bovinos leiteiros com queixa de queda de produção, emagrecimento e mortalidade, e utilizar o esfregaço em capa leucocitária ou a PCR específica para confirmar o diagnóstico. Contudo, como demonstrado neste trabalho, o uso da PCR, por apresentar maior sensibilidade que a detecção do parasito em capa leucocitária, deve ser considerado para se reduzir resultados falsos negativos. 